\title{
Mucosal and cutaneous lesions in mandibular zoster
}

\author{
Zacharias Vourexakis, Julie Vanoy
}

Department of Otolaryngology/ Head and Neck Surgery, University Hospital of Geneva, Geneva, Switzerland

\section{Correspondence to} Dr Zacharias Vourexakis, zkvourexakis@yahoo.com

Accepted 13 March 2014
CrossMark

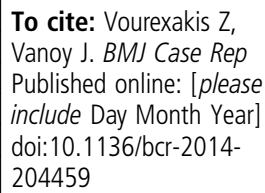

To cite: Vourexakis Z, Vanoy J. BMJ Case Rep Published online: [please include Day Month Year] doi:10.1136/bcr-2014204459

\section{DESCRIPTION}

An otherwise healthy 23-year-old man presented to ear, nose and throat clinic with burning sensation in the mouth since 5 days, followed 4 days later by a vesicular skin eruption on half of the lower lip and extending to the ipsilateral cheek (figure 1).

Oral inspection revealed well circumscribed, fibrin-covered 'patches' on the mobile tongue, more marked on its ventral surface (figure 2A) and multiple vesicles on the mucosa of the cheek (figure 2B) and the palatoglossal arch. All lesions were strictly limited on the left side.

Varicella-zoster virus (VZV) DNA was detected by PCR on a swab from the cutaneous lesions, confirming the diagnosis of mandibular zoster.

A month after complete regression of all acute lesions, skin hyperpigmentation and recurrent sensation of burning and stinging pain on the skin and the mouth were still persisting.

The pictures illustrate mucosal and cutaneous lesions' distribution following sensory fibres of the mandibular nerve.

Primary infection with VZV results in varicella. As symptoms resolve, viral particles stay dormant in the sensory ganglia of the peripheral nervous system. Reactivation occurs in $30 \%$ of infected individuals ${ }^{1}$ resulting in herpes zoster with characteristic dermatome distribution.

The branch of the trigeminal nerve which is most often affected is the ophthalmic nerve. Mandibular nerve involvement is much rarer and

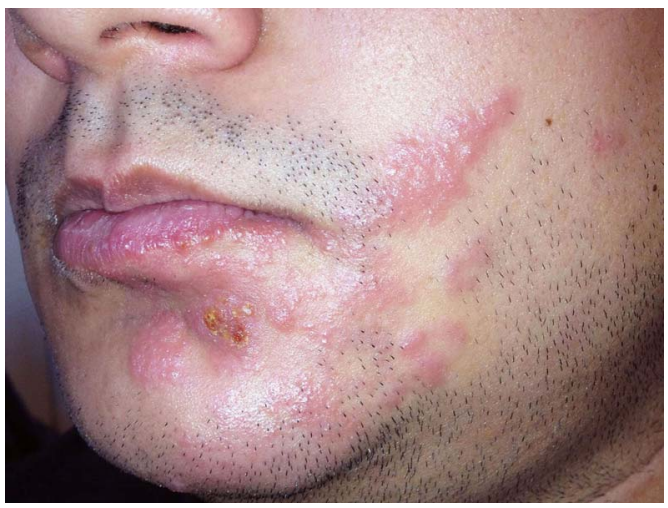

Figure 1 Cutaneous lesions of mandibular zoster on the cheek, the lower lip and the chin, all limited to the left side.
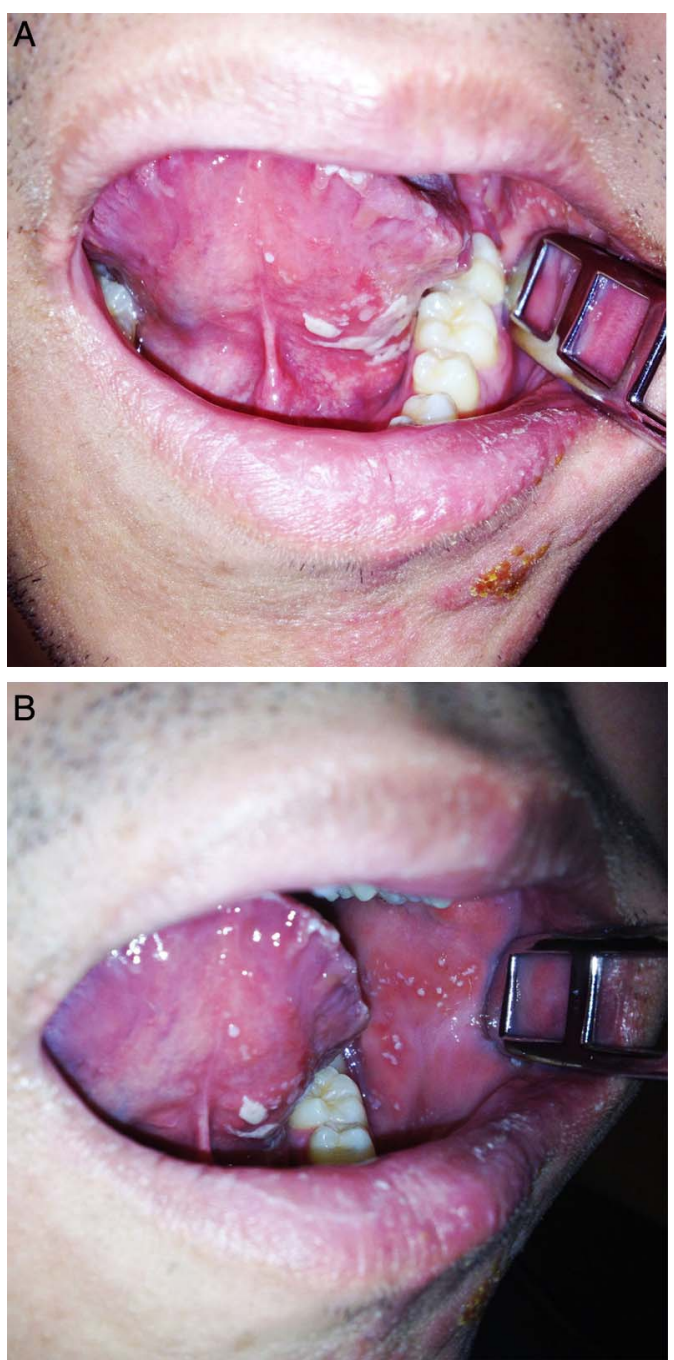

Figure 2 (A) Oral lesions of mandibular zoster occupying the tongue, the floor of the mouth and the cheek mucosa. (B) Vesicles of mandibular zoster on the cheek mucosa and lesions on the ventral surface of the mobile tongue.

may be accompanied by gustatory dysfunction in addition to other symptoms of zoster. Complications include postherpetic neuralgia and skin alterations (pigmentation or scarring) while rare cases of dental and mandibular involvement have been described. ${ }^{2}$ Early prescription of antiviral agents hastens acute symptoms' resolution and possibly decreases the risk of postherpetic neuralgia. ${ }^{3}$ 


\section{Learning points}

- The mandibular nerve carries motor and sensory fibres, the latter distributed to part of the face and the mouth (temporal region, part of the pinna, cheek, chin, lower lip, cheek mucosa, floor of the mouth and anterior $2 / 3$ of the tongue). Moreover, the lingual nerve's connection to the corda tympani transfers taste fibres from the mobile tongue and parasympathetic fibres to the submandibular ganglion.

- Zoster limited to the mandibular nerve is relatively rare compared to ophthalmic zoster, but not exceptional in clinical practice.

- Early initiation of antiviral treatment accelerates recovery and may decrease the risk of postherpetic neuralgia.
Competing interests None.

Patient consent Obtained.

Provenance and peer review Not commissioned; externally peer reviewed.

\section{REFERENCES}

1 Gershon AA, Gershon MD. Perspectives on vaccines against varicella-zoster virus infections. Varicella-zoster virus. BerlinHeidelberg: Springer-Verlag, 2010:359.

2 Schwartz 0, Kvorning SA. Tooth exfoliation, osteonecrosis of the jaw and neuralgia following herpes zoster of the trigeminal nerve. Int I Oral Surg 1982;11:364-71.

3 Albrecht MA. Treatment of herpes zoster in the immunocompetent host. UpToDate, $10 \mathrm{Jul}$ 2013. http://www.uptodate.com/contents/treatment-of-herpes-zoster-in-theimmunocompetent-host.

Copyright 2014 BMJ Publishing Group. All rights reserved. For permission to reuse any of this content visit

http://group.bmj.com/group/rights-licensing/permissions.

BMJ Case Report Fellows may re-use this article for personal use and teaching without any further permission.

Become a Fellow of BMJ Case Reports today and you can:

- Submit as many cases as you like

- Enjoy fast sympathetic peer review and rapid publication of accepted articles

- Access all the published articles

- Re-use any of the published material for personal use and teaching without further permission

For information on Institutional Fellowships contact consortiasales@bmjgroup.com

Visit casereports.bmj.com for more articles like this and to become a Fellow 